\title{
Development of a Low Solution Resistance Type Solution Flow Droplet Cell and Investigation of Its Electrochemical Performance
}

\author{
Masatoshi SAKAIRI, ${ }^{1)}$ Takuya MURATA, ${ }^{2)}$ Tatsuya KIKUCHI ${ }^{1)}$ and Koji FUSHIMI ${ }^{1)}$ \\ 1) Faculty of Engineering, Hokkaido University, Kita-13, Nishi-8, Kita-ku, Sapporo 060-8628 Japan. \\ 2) Graduate School of Engineering, Hokkaido University, Kita-13, Nishi-8, Kita-ku, Sapporo 060-8628 Japan.
}

(Received on April 5, 2010; accepted on July 2, 2010)

\begin{abstract}
A solution resistance reduced solution flow type micro-droplet cell with co-axial dual capillary tubes was developed. A Pt counter electrode wire, $50 \mu \mathrm{m}$ diameter, inserted in the inner capillary tube, successfully reduced solution resistance between the working and counter electrodes. The potentio-dynamic polarization measurements showed the electrochemical performance of developed droplet cell to be very similar to that of traditional macro sized electrochemical cells. The developed droplet cell was applied to obtain line profiles of a current at a constant potential across the surface of for cross-sections of model metal interfaces. The current changed at the model interface between deposited nickel and substrate, and the spatial resolution of the developed droplet cell was reduced with increasing scanning speed of the cell. The results reported in this paper suggest that this technique would be able to measure differences in corrosion resistance in welded metal components and base metals.
\end{abstract}

KEY WORDS: solution flow type droplet cell; local electrochemistry; corrosion.

\section{Introduction}

The micro-droplet cell technique is a widely applied tool to measure local electro chemical behaviors or mask-less local surface treatments. Two different types of droplet cells are in use, one uses an electrolyte droplet, which stands free from the capillary tip due to the balance between the electrolyte surface tension and the local surface of the specimen electrode. ${ }^{1,2)}$ The other employs silicone rubber at the tip of the capillary tube as a gasket to avoid outflow of solution over the specimen surface. ${ }^{3-6)}$ A problem with these droplet cells is that electrolyte composition changes during experiments. To avoid electrolyte composition changes, a solution flow type droplet cell equipped with a gasket at the tip of the capillary tube has been proposed. Lohrengel et al. reported such a solution flow type droplet cell, ${ }^{7-9)}$ where it would however be difficult to move the droplet while the droplet is in contact with a specimen.

One of the authors here, Fushimi, has developed a solution flow-type droplet cell with co-axial dual capillary tubes, ${ }^{10)}$ solving many of the problems of conventional droplet cells. This solution flow type droplet cell has been applied to measure cross-section corrosion potential profiles of aluminum-alloy brazing sheets, and to investigate the electrochemical behavior of welded low carbon 13 mass\% Cr stainless steels by Nakayama et al. ${ }^{11)}$ and Hashizume et al. ${ }^{12)}$ This cell was also applied to fabricate $\mathrm{Ni}$ micro-rods ${ }^{13)}$ and $\mathrm{Cu}$ components with high aspect ratios, ${ }^{14)} \mathrm{Cu}$ branched micro-rods, and $\mathrm{Ni} / \mathrm{Cu}$ layered micro- rods. ${ }^{15)}$ The cell has disadvantages such as the requirement for a two electrode system, high solution resistance and inadequate spatial resolution. Therefore, there is a need to develop a new type of droplet cell where it is possible to measure local electrochemical parameters of commercially available steel components.

The purpose of this study is to report the development of such a new low solution resistance and three electrode type droplet cell, overcoming many of the shortcomings detailed above, and investigate the electrochemical performance of the developed droplet cell.

\section{Development of the New Droplet Cell}

Figure 1 shows a schematic drawing of a) a cross section of the new three electrode type droplet cell, and b) an enlargement of the tip of the cell. The main part and outer tube of the cell is made of polypropylene and the inner capillary tube is made of silica glass with an inside diameter of $100 \mu \mathrm{m}$ and an outside diameter of $200 \mu \mathrm{m}$. An $\mathrm{AgCl}$ coated Ag wire, ${ }^{16)}$ which is fitted at the top of the cell was used as reference electrode. Figure 2 shows the potential differences, $\Delta E$, between the $\mathrm{AgCl}$ coated $\mathrm{Ag}$ wire and an $\mathrm{Ag} / \mathrm{AgCl}$ sat. $\mathrm{KCl}$ reference electrode (commercially available) as a function of chloride ion concentration. The $\Delta E$ decreases with $\log \left[\mathrm{Cl}^{-}\right]$, and the $\mathrm{AgCl}$ coated $\mathrm{Ag}$ wire reference electrode also showed good potential stability and durability. These results indicate that $\mathrm{AgCl}$ coated $\mathrm{Ag}$ wire electrodes can be used for electrochemical measurements 

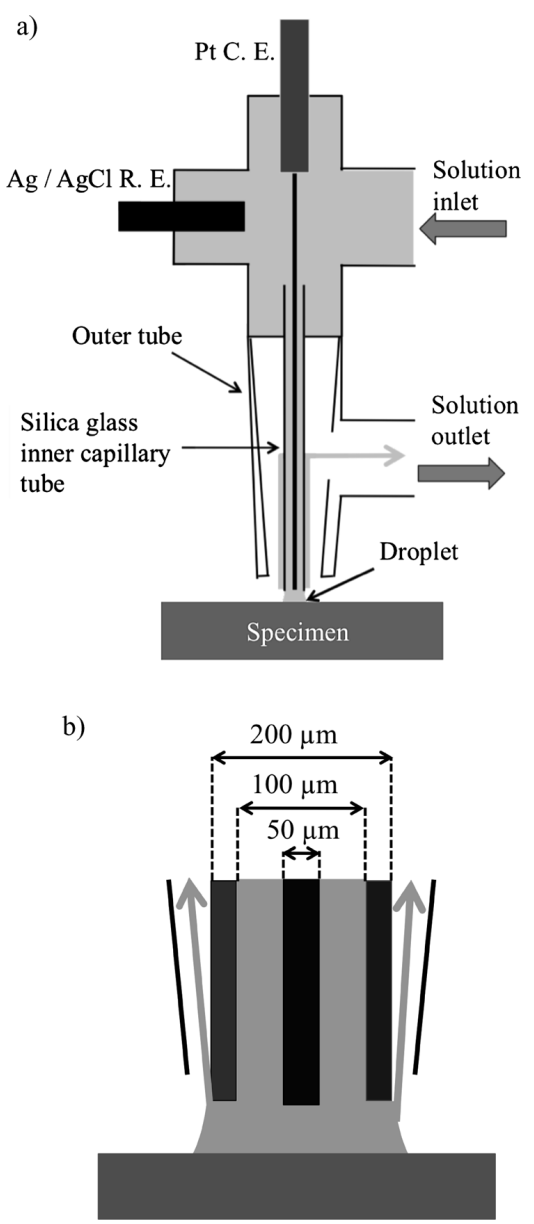

Fig. 1. Schematic outline of a) a cross section of the newly developed three electrode type droplet cell and b) an enlarged sketch of the tip of the cell.

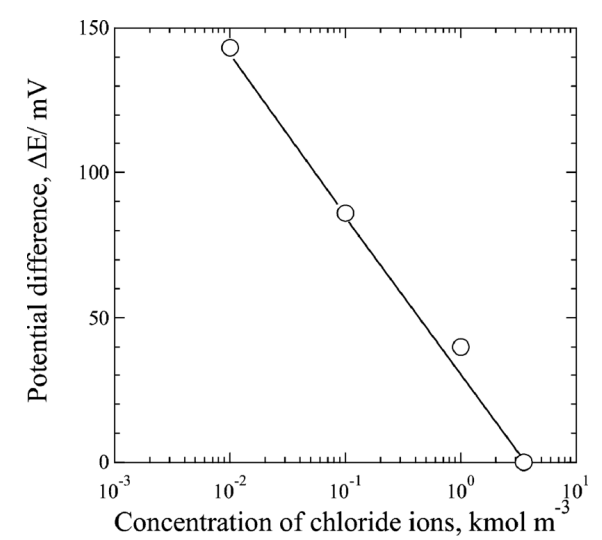

Fig. 2. Potential differences between the $\mathrm{AgCl}$ coated $\mathrm{Ag}$ wire and the $\mathrm{Ag} / \mathrm{AgCl}$ sat. $\mathrm{KCl}$ reference electrode as a function of chloride ion concentration.

with the developed droplet cell. A Pt wire $(50 \mu \mathrm{m}$ in diameter) is used as a counter electrode. The Pt wire is inserted in the silica glass capillary tube to reduce solution resistance, and the tip of the Pt wire is adjusted to fit at the tip of the inner capillary tube. The solution flow mode in the capillary tube would not be affected by the inserted Pt wire, because $75 \%$ of the inside cross sectional area of the capillary tube remains available for the solution flow. Figure 3 shows a) an enlarged photo of the developed droplet cell and $\mathrm{b}$ ) the used $\mathrm{AgCl}$ coated $\mathrm{Ag}$ wire reference electrode.
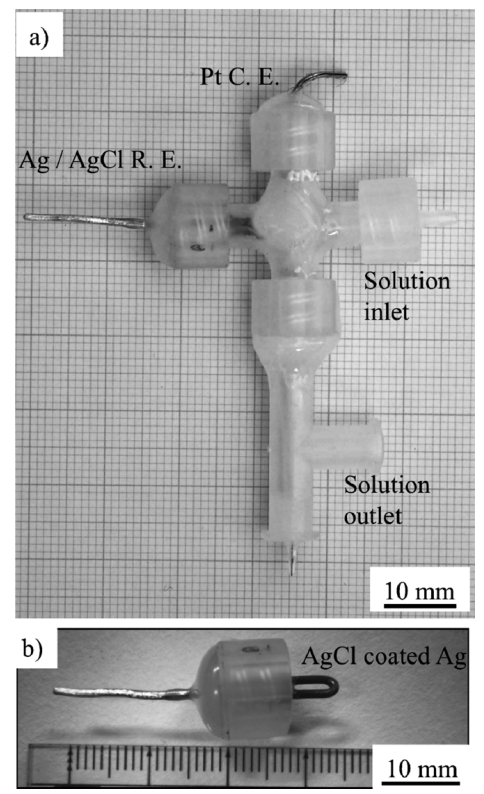

Fig. 3. Photograph of the developed droplet cell and the $\mathrm{AgCl}$ coated Ag reference electrode.

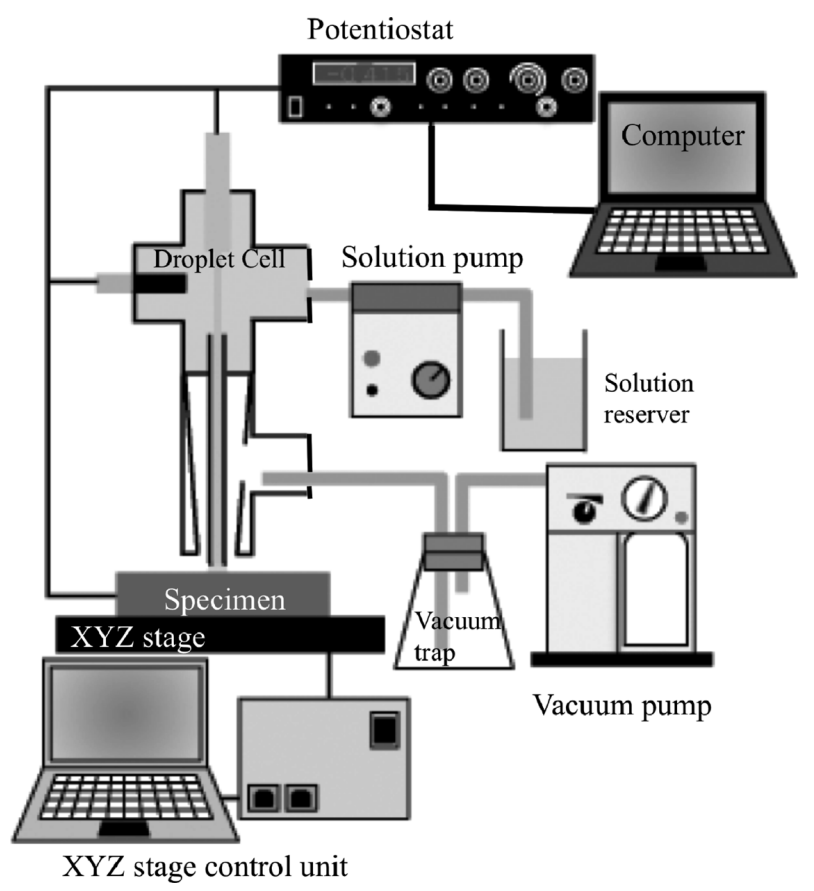

Fig. 4. Schematic view of the electrochemical measurement system used here.

Figure 4 is a schematic representation of the XYZ position controllable micro-droplet cell based electrochemical measurement system presented here. A droplet of solution is formed between the specimen surface and the tip of the co-axial double capillary tube. The inner capillary tube receives solution from the inlet, supplying fresh electrolyte solution to the droplet from the solution reservoir while the outer capillary removes depleted solution from the droplet with a vacuum pump and solution trap. After forming the droplet at the tip of the inner capillary tube, the specimen (placed on a computer controlled XYZ stage) is moved into contact with the droplet, and the local electrochemical behavior is measured. 


\section{Experimental}

\subsection{Specimen and Solution}

Commercially available pure iron, copper and nickel sheets (The Nirako Co., Japan) were used to investigate the basic electrochemical performance of the developed cell. A copper or iron sheet with nickel deposited on parts of the surface were used as model specimens for the measurements of the local electrochemical behavior. To investigate the effect of height differences at the surface, different thicknesses, $d$, of nickel layers were deposited on an iron sheet. Before use, the specimens were cleaned in ethanol and in doubly distilled water in an ultrasonic bath. After cleaning, the specimen was set on a computer controlled pulse-XYZ stage as suggested in Fig. 4.

The solution used as the electrolyte was $0.5 \mathrm{kmol} \mathrm{m}^{-3}$ $\mathrm{H}_{3} \mathrm{BO}_{3} / 0.05 \mathrm{kmol} \mathrm{m}^{-3} \mathrm{Na}_{2} \mathrm{~B}_{4} \mathrm{O}_{7}$ with 0.01 or $0.1 \mathrm{kmol} \mathrm{m}^{-3}$ $\mathrm{NaCl}$ solution. A droplet of electrolyte was formed at the tip of the inner capillary by setting the solution flow rate to $8.33 \times 10^{-10} \mathrm{~m}^{3} \mathrm{~s}^{-1}$ and the vacuum pressure to $70 \mathrm{kPa}$ at the vacuum pump.

\subsection{Electrochemical Measurements and Surface Observation}

Potentio-dynamic polarization curves for each specimen were measured by both the developed solution flow type droplet cell and a traditional three electrode cell, macro sized cell. The potential sweep rate was $1 \mathrm{mV} \mathrm{s}^{-1}$. Current changes during the continuous droplet cell movement in one direction at a constant applied potential was measured to investigate the ability of the developed droplet cell to measure local electrochemical behavior differences of the model specimens. The distance between the specimen surface and the tip of the inner capillary tube (tip of the counter electrode) was adjusted to be shorter than $20 \mu \mathrm{m}$.

The model specimen surface was observed by a confocal scanning laser microscope (CSLM; 1SA21, LASERTEC Co.), and the height of the deposits was measured with the height analysis function of CSLM.

\section{Results and Discussion}

\subsection{Polarization Measurement}

Anodic potentio-dynamic polarization curves for iron, copper, and nickel sheets in $0.5 \mathrm{kmol} \mathrm{m}^{-3} \mathrm{H}_{3} \mathrm{BO}_{3} / 0.05 \mathrm{kmol}$ $\mathrm{m}^{-3} \mathrm{Na}_{2} \mathrm{~B}_{4} \mathrm{O}_{7}$ with $0.01 \mathrm{kmol} \mathrm{m}^{-3} \mathrm{NaCl}$ are shown in Fig. 5. The polarization curves of each specimen measured by the macro sized cell are also shown in the Fig. 5. For the iron and nickel specimens, the rest potential measured by the droplet-cell is very similar to that measured by the macro sized cell, however, the potentials of the copper specimen measured by the droplet cell is about $100 \mathrm{mV}$ lower than those measured by the macro sized cell. The rest potential is a balance of the anodic reaction rate, the dissolution rate of the metal; and the cathodic reaction rate, the oxygen reduction rate. The cathodic reaction site of the droplet-cell may be the rim of the droplet, where the electrolyte thickness may be thinner than at the middle of the droplet. This means that the cathodic reaction, especially on the copper, can be accelerated to move the rest potential to the anodic region. As the potential moves to the anodic
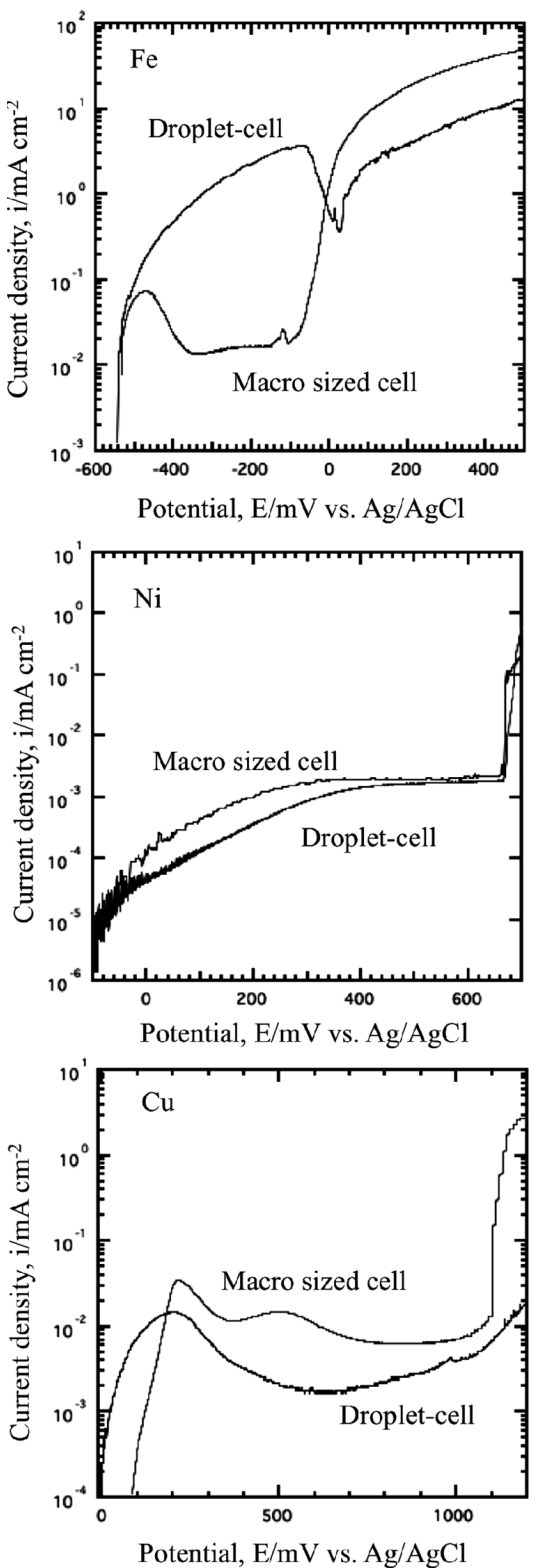

Fig. 5. Potentio-dynamic polarization curves iron, copper and nickel in $0.5 \mathrm{kmol} \mathrm{m}^{-3} \mathrm{H}_{3} \mathrm{BO}_{3} / 0.05 \mathrm{kmol} \mathrm{m}^{-3} \mathrm{Na}_{2} \mathrm{~B}_{4} \mathrm{O}_{7}$ with $0.01 \mathrm{kmol} \mathrm{m}^{-3} \mathrm{NaCl}$ by the droplet cell and macro cell.

direction, the current increases slowly and shows a passive region then rapidly increases in all the experiments, expect for the results with iron by the droplet cell. However, the polarization behaviors of both cells were very similar in $0.5 \mathrm{kmol} \mathrm{m}^{-3} \mathrm{H}_{3} \mathrm{BO}_{3} / 0.05 \mathrm{kmol} \mathrm{m}^{-3} \mathrm{Na}_{2} \mathrm{~B}_{4} \mathrm{O}_{7}$. The reason why the polarization behavior of iron by the droplet cell is different from that of the macro sized cell in $\mathrm{Cl}^{-}$containing solutions is not clear, one reason may be that $\mathrm{Cl}^{-}$ions influence the polarization behavior of iron. These polarization behavior characteristics show that the developed droplet cell can be used in electrochemical experiments.

\subsection{Current Measurements During Line Scanning}

The constant potential used in the current measurements during the line scanning with the cell was selected based on the polarization curves for each metal.

Figure 6 shows the current profiles with the droplet cell during two line scans moving from copper substrate (left) to 


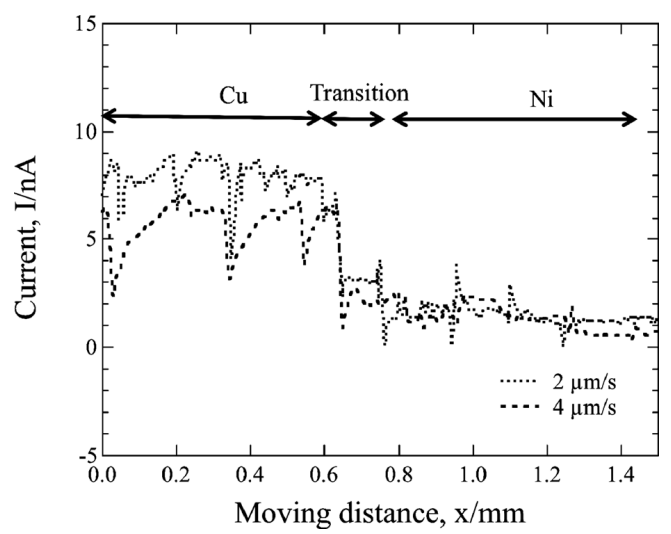

Fig. 6. Current profiles on a line scan from the surface of a copper substrate to a section with nickel deposited on the copper. Applied potential $-120 \mathrm{mV}$, and in $0.5 \mathrm{kmol} \mathrm{m}^{-3}$ $\mathrm{H}_{3} \mathrm{BO}_{3} / 0.05 \mathrm{kmol} \mathrm{m}^{-3} \mathrm{Na}_{2} \mathrm{~B}_{4} \mathrm{O}_{7}$ with $0.1 \mathrm{kmol} \mathrm{m}^{-3} \mathrm{NaCl}$.

an area with nickel deposited on the copper, the scan was performed at a constant potential of $-120 \mathrm{mV}$ in $0.5 \mathrm{kmol}$ $\mathrm{m}^{-3} \quad \mathrm{H}_{3} \mathrm{BO}_{3} / 0.05 \mathrm{kmol} \mathrm{m}^{-3} \quad \mathrm{Na}_{2} \mathrm{~B}_{4} \mathrm{O}_{7}$ with $0.1 \mathrm{kmol} \mathrm{m}^{-3}$ $\mathrm{NaCl}$ at scanning rates of 2 and $4 \mu \mathrm{m} / \mathrm{s}$. The current is about $6 \mathrm{nA}$ across the copper substrate and decreases to about $2 \mathrm{nA}$ on the nickel deposited area. These results suggest that this technique is able to measure interfaces of different metals.

When this technique is applied to measure electrochemical differences of metal surfaces, real metal surfaces will display some roughness, and the droplet shape or stability during the scanning could be affected by the surface roughness. Therefore, it is important to investigate the effect of the surface roughness on the electrochemical measurements during the scanning by the droplet cell. To investigate the effect of surface roughness, different thicknesses of nickel deposited on iron model specimens were used, and the effect of the cell scanning rate on the spatial resolution of the cell was also investigated.

Figure 7 shows the current profiles in the line scan from an area of nickel deposited on iron substrate, deposited thickness $d=1 \mu \mathrm{m}$, to the iron substrate at different scanning rates at a constant potential of $-300 \mathrm{mV}$ in 0.5 $\mathrm{kmol} \mathrm{m}^{-3} \mathrm{H}_{3} \mathrm{BO}_{3} / 0.05 \mathrm{kmol} \mathrm{m}^{-3} \mathrm{Na}_{2} \mathrm{~B}_{4} \mathrm{O}_{7}$ with $0.1 \mathrm{kmol} \mathrm{m}^{-3}$ $\mathrm{NaCl}$. The surface image and height profile obtained by CSLM are also shown in the Fig. 7. In all scanning rates of the droplet cell, the current is low while the droplet cell is in contact with the nickel deposited area, the current increases when the droplet cell is in contact with the iron substrate. The current change at the section between nickel and iron becomes sharper with slower droplet cell scanning rates.

The current profiles during the line scan from the nickel deposited area to the iron substrate at different scanning rates of the cell at the constant potential of $-300 \mathrm{mV}$ in 0.5 $\mathrm{kmol} \mathrm{m}^{-3} \quad \mathrm{H}_{3} \mathrm{BO}_{3} / 0.05 \mathrm{kmol} \mathrm{m}^{-3} \quad \mathrm{Na}_{2} \mathrm{~B}_{4} \mathrm{O}_{7}$ with $0.1 \mathrm{kmol}$ $\mathrm{m}^{-3} \mathrm{NaCl}$ are shown in Fig. $8(d=5 \mu \mathrm{m})$ and Fig. $9(d=$ $10 \mu \mathrm{m})$. The surface images and height profiles obtained by CSLM are also shown in the Figs. 8 and 9. The current profiles are very similar to those in Fig. 7. The current profile in both specimens at the section between the nickel and the iron also become sharper with slower droplet cell scanning rates. It indicates that the developed droplet cell can meas-
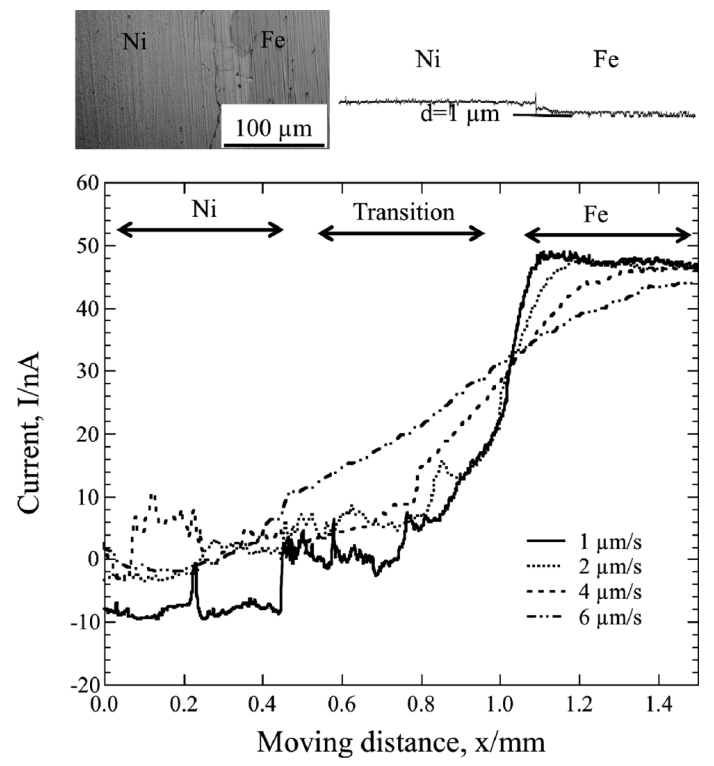

Fig. 7. Current profiles of a line scan from a nickel covered area to the iron substrate at different scanning rates, and surface image and height profile obtained by CSLM. The applied potential was $-300 \mathrm{mV}$, and the solution was 0.5 $\mathrm{kmol} \mathrm{m}^{-3} \mathrm{H}_{3} \mathrm{BO}_{3} / 0.05 \mathrm{kmol} \mathrm{m}^{-3} \mathrm{Na}_{2} \mathrm{~B}_{4} \mathrm{O}_{7}$ with $0.1 \mathrm{kmol}$ $\mathrm{m}^{-3} \mathrm{NaCl}$. The deposited nickel thickness was $1 \mu \mathrm{m}$.
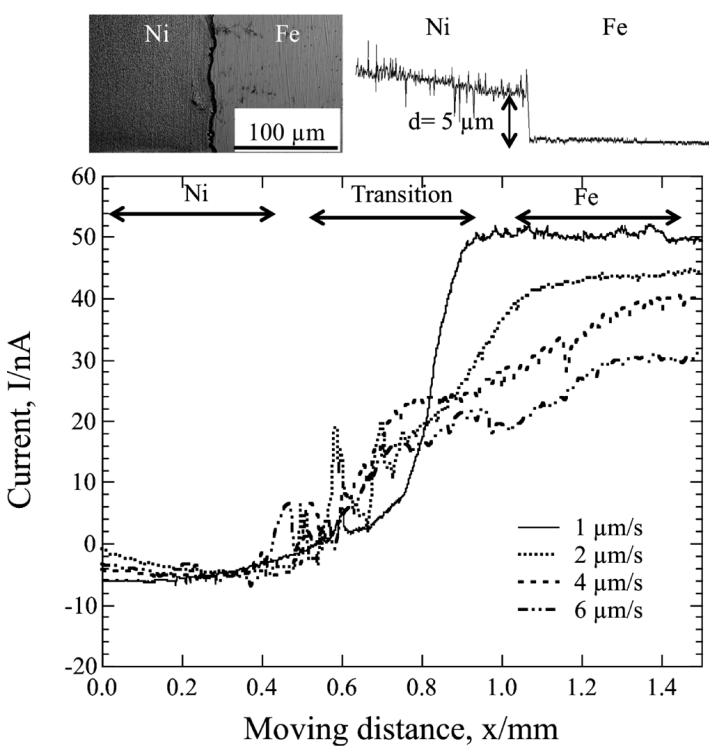

Fig. 8. Current profiles of a line scan across nickel deposited on iron and the iron substrate at different scanning rates, with surface image and height profile obtained by CSLM. The applied potential was $-300 \mathrm{mV}$, and the solution was $0.5 \mathrm{kmol} \mathrm{m}^{-3} \quad \mathrm{H}_{3} \mathrm{BO}_{3} / 0.05 \mathrm{kmol} \mathrm{m}^{-3} \quad \mathrm{Na}_{2} \mathrm{~B}_{4} \mathrm{O}_{7}$ with 0.1 $\mathrm{kmol} \mathrm{m}^{-3} \mathrm{NaCl}$. The deposited nickel thickness was $5 \mu \mathrm{m}$.

ure current profiles of uneven surfaces with a maximum roughness of about $10 \mu \mathrm{m}$.

To investigate the spatial resolution of the developed cell in order to evaluate the ability to measure the boundary between different metals, the distance between the current transition of one metal to the other metal in the current profiles of Figs. 7, 8, and 9 was measured. This distance, when measuring the current on nickel and on iron across the transition between the two metals, as a function of droplet cell scanning rate is shown in Fig. 10. The distance increases with increasing droplet cell scanning rates in all three sam- 

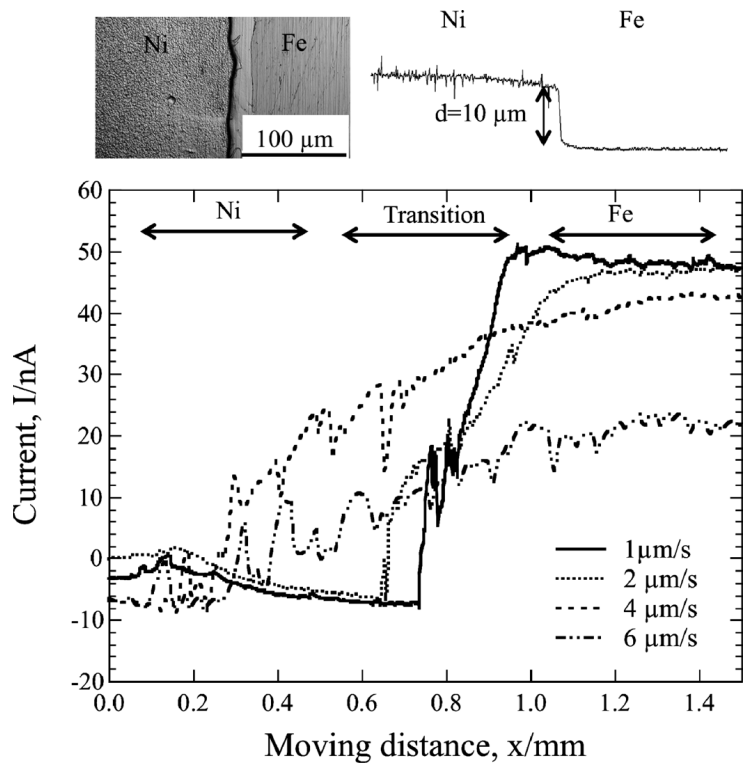

Fig. 9. Current profiles of a line scan across nickel deposited on iron and the iron substrate at different scanning rates, with a surface image and height profile obtained by CSLM. The applied potential was $-300 \mathrm{mV}$, and the solution was $0.5 \mathrm{kmol} \mathrm{m}^{-3} \mathrm{H}_{3} \mathrm{BO}_{3} / 0.05 \mathrm{kmol} \mathrm{m}^{-3} \mathrm{Na}_{2} \mathrm{~B}_{4} \mathrm{O}_{7}$ with $0.1 \mathrm{kmol} \mathrm{m}^{-3} \mathrm{NaCl}$. The deposited nickel thickness was $10 \mu \mathrm{m}$.

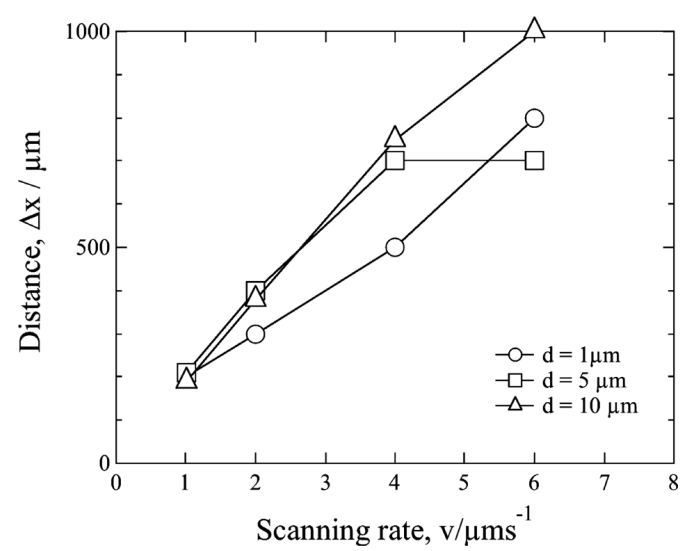

Fig. 10. The length of the transition (distance) between the two surface conditions, deposited nickel and iron substrate, for the droplet-cell in Figs. 7, 8, and 9 as a function of droplet cell scanning rate.

ples measured here. The minimum distance for the current transiton, or spatial resolution, in these experiments is about $200 \mu \mathrm{m}$, which is almost the same as the outside diameter of the used inner capillary tube. This spatial resolution is inadequate to measure electrochemical parameter differences of each crystal grain in polycrystal metals or at the segregations or boundaries in welded components. The spatial resolution may however be improved by using a finer counter electrode or modified electrode geometry.

\section{Conclusions}

A new low solution resistance and three electrode type droplet cell was developed, and the electrochemical performance of the developed cell was investigated. The following conclusions may be drawn.

(1) The electrochemical behavior of the developed cell was investigated by polarization measurements. The electrochemical behavior of the developed cell and macro sized cells are very similar.

(2) The current profile of model interface specimens can be measured by the scanning droplet cell at constant potentials. The distance of the current change of current profiles increase with increasing droplet cell scanning rate. The minimum distance of the current changes or spatial resolution achieved in this experiment was about $200 \mu \mathrm{m}$.

(3) The developed cell can measure the current profile at height differences in the specimen surfaces.

\section{Acknowledgement}

The authors are indebted for financial support from the The Iron and Steel Institute of Japan, ISIJ Research Promotion Grant.

\section{REFERENCES}

1) M. M. Lohrengel: Electrochim. Acta, 42 (1997), 3265

2) M. Pilaski and M. M. Lohrengel: Electrochim. Acta, 48 (2003), 1309.

3) T. Suter and H. Boehni: Electrochim. Acta, 43 (1998), 2843.

4) H. Boehni, T. Suter and F. Assi: Surf. Coat. Technol., 130 (2000), 80.

5) A. Schreiber, C. Rosenkranz and M. M. Lohrengel: Electrochim. Acta, 52 (2007), 7738

6) I. Muto, Y. Izumiyama and N. Hara: J. Electrochem. Soc., 154 (2007), C439.

7) M. M. Lohrengel, I. Klüppel, C. Rosenkranz, H. Bettermann and J. W. Schultze, Electrochim. Acta, 48 (2003), 3203.

8) B. Walther, J. Schilm, A. Michaelis and M. M. Lohrengel: Electrochim. Acta, 52 (2007), 7732.

9) K. A. Lill, A. W. Hassel, G. Frommeyer and M. Stratmann: Electrochim. Acta, 51 (2005), 978.

10) K. Fushimi, S. Yamamoto, R. Ozaki and H. Habazaki: Electrochimica Acta, 53 (2008), 2529.

11) T. Nakayama, M. Sakairi, K. Fushimi and S. Hashizume: Proc. of Eurocorr 07, (2007), paper 1130.

12) S. Hashizume, Nakayama, M. Sakairi and K. Fushimi, Proc. of NACE2008, NACE International, Houton, TX, (2008), paper 08102.

13) M. Sakairi, T. Nakayama, T. Kikuchi, S. Hashizume and K. Fushimi: ECS Trans., 52 (2009), 281.

14) M. Sakairi, F. Sato, Y. Gotou, K. Fushimi, T. Kikuchi and H. Takahashi: Electorochim. Acta, 54 (2008), 616.

15) M. Sakairi, Y. Goto, T. Kikuchi, K. Fushimi and H. Takahashi: Electrochemistry, 78 (2010), 118.

16) T. Tsuru, M. Itagaki, K. Hashimoto and A. Nishikata: Corros. Eng. (Jpn.), 37 (1988), 361 